\title{
DOES MISPRICING AFFECT INVESTMENT AND CAPITAL STRUCTURE OF INDONESIAN FIRMS?
}

\author{
Risal Rinofah, Irwan Trinugroho
}

Faculty of Economics, Sebelas Maret University

\begin{abstract}
Stock price movement is not entirely a reflection of its fundamental value because of there are non-fundamental factors such as market sentiment (Keynes, 1936), behavioral biases of investors (Lakonishok et al., 1994), systematic errors when assessing stock (Stein, 1996), asymmetric information (Tobin, 1969) causing the value of stock deviate from its fundamental value (misprice). This condition can affect corporate investment decisions because managers can take advantage of overvalued stock condition as a source of investment funding because the cost of capital becomes cheaper. Conversely, firms avoid selling stocks at undervalued due to high cost of capital. Therefore, the objectives of this research is to examine the effect of mispricing to firms investment behavior and to firms capital structure. We also test the role of the level of financial constraint in the relationship between mispricing and investment.

Using panel data regression with data observation for five years, we find that mispricing have positif impact to firms investment level. However, this effect is not diverse whether on a group of firms which have a high level of financial constraint (financially constraint) or those which have a low level of financial constraint (less constraint). Moreover, this research also find that the mispricing can also influence firms in choosing sources of funding which can be seen on their debt to equity ratio (D/E). To check the accuracy of examination, we employ some robustness test and use several control variables. These results are consistent with and can be explained using market timing and catering hypotesis.
\end{abstract}

Keywords: Mispricing, investment, capital structure, financial constraint, market timing hypothesis, catering hypothesis 